\title{
Diplomatic Gifts, Tributes and Frontier Violence: Circulation of Contentious Presents in the Moluccas (1575-1606)
}

\author{
Jose M. Escribano-Páez \\ Universidad Pablo de Olavide, Seville, Spain \\ Jose.Escribano@eui.eu
}

\begin{abstract}
A crucial asset for cross-cultural communication during the early modern period, diplomatic gifts have been traditionally associated with courtly diplomacy and peaceful encounters. However, recent scholarship on this topic has emphasized how gifts can reveal bitter political rivalries and asymmetries of power. Building on this line of inquiry, this article explores the complex roles of gifts in the dynamics of crosscultural violence on the frontiers of the Iberian empires in Southeast Asia. Through the examination of a wide array of sources, I aim to show how gift-giving turned into one of the multiple factors fueling the violent conflict between Moluccan sultans and Iberian authorities in the region between 1575 and 1606.
\end{abstract}

\section{Keywords}

gift-giving - cross-cultural diplomacy - Maluku - Philippines - Iberian empires sixteenth century

\section{Introduction}

In 1605 Said Syah, Sultan of Ternate, sent a letter to King James I of England rejecting the latter's demand to establish a factory on his island. To justify his decision, he wrote: 
When Francis Drake came here when the late one [Sultan Babullah] was still alive, he gave Francis Drake a message, accompanied by a token in the form of a ring, to be conveyed to our friend the Sovereign of England [Queen Elizabeth]. God is witness to the late one's request to Francis Drake, but for over twenty years no news at all was received... And right till the present there was never any sign from the English of their desire for an alliance with the people of Maluku. ${ }^{1}$

Once in Europe, the letter was to live a life of its own. ${ }^{2}$ For European audiences, the diplomatic negotiations between the Sultan of Ternate and the European rulers was of outstanding interest due to the ongoing global spice wars. Undoubtedly, the story of a sultan refusing to grant commercial privileges because of past grievances had an exotic touch, but the obvious meaning of the gift at the center of the story allowed European audiences to easily understand what was going on. From a European perspective rings were the best way to express a strong relationship, such as an alliance. Any reader familiar with the history of the Dutch and English East India companies would consider the letter as a precedent of their violent rivalry in the Spice Islands. ${ }^{3}$ However, the letter also encapsulates the long history of contentious gifts circulating in the Moluccas during the last quarter of the sixteenth century. This article does not focus on the seventeenth-century wars to control the spice trade which lie at the base of the ring's diplomatic incident and the global attention it raised, but on the violent escalation which began after the expulsion of the Portuguese from Ternate (1575), leading to the Spanish conquest of the island (1606). The conflict between Iberians and Moluccans has been paid attention by a wide array of scholars, who have largely focused on discussing the role played by the religious divide. ${ }^{4}$ Without dismissing the importance of

1 Gallop, A. "Seventeenth-Century Indonesian Letters in the Public Record Office." Indonesia and the Malay World 31 (2003), 417.

2 Farrington, J. "The First Twelve Voyages of the English East India Company, 1601-13: A Guide to Sources." Indonesia and the Malay World 29 (2001), 144-45; Biblioteca Nacional de España, R/14034, 6; Argensola, B. Conquista de las islas Malucas (Madrid: Alonso Martín, 16o9), 263-64; Purchas, S. Purchas his Pilgrimes, or Hakluytus Posthumus (London: William Stansby, 1625), 704-5.

3 Games, A. "Anglo-Dutch Maritime Interactions in the East Indies During the Early Seventeenth Century." In Governing the Sea in the Early Modern Era, eds. P. Mancall and C. Shammas (San Marino: The Huntington Library, 2015), 171-95; Loth, V. "Armed Incidents and Unpaid Bills: Anglo-Dutch Rivalry in the Banda Islands in the Seventeenth Century." Modern Asian Studies, 29 (1995), 705-40; Bassett, D. “The 'Amboyna Massacre' of 1623." Journal of Southeast Asian History, 1 (1960), 1-19.

4 Kartodirdjo, S. "Religious and Economic Aspects of Portuguese-Indonesian Relations." Stvdia 29 (1970), 175-196; Reid, A. Southeast Asia in the Early Modern Era: Trade, Power and Belief 
religion-driven violence, or the economic motivations of both sides, I aim at exploring another dimension in this violent escalation: the conflicts and hostilities related to diplomatic gift-giving and tributes. It is not my contention to show that conflicts over gifts and tributes were the main factor in this violent escalation, but to understand what role diplomatic gifts and tributes played in it. In so doing, I aim at contributing to a recent debate that explores the role of diplomatic gift-giving in cross-cultural conflicts during the early modern period.

Gift-giving has been widely understood as a pacific tool to forge social and political bonds. ${ }^{5}$ However, in recent years increasing attention has been paid to the relationship between the exchange of diplomatic gifts or tributes and political rivalries or violent power asymmetries. It is a well-known fact that the diplomatic gifts presented by Europeans caused offense to, and hampered their negotiations with, non-European potentates, due to the Europeans' failure to decode gift-giving traditions that were unknown to them. ${ }^{6}$ Without ignoring the relevance of differences in diplomatic cultures, recent scholarship has emphasized the weaponization of diplomatic gifts and tributes. A major case in point is the European widespread practice of instrumentalizing gifts to extend and legitimize the violent annexation of overseas territories and peoples. ${ }^{7}$ However, the weaponization of cross-cultural gift-giving, was no European monopoly since Asian rulers also established their dominance over

(Ithaca: Cornell University Press, 1993), 165-166; Lobato, M. "Épices, conflit et religion. Les Moluques et les Portugais dans la seconde moitié du XVIe Siècle." Nouvelles orientations de la Recherche sur l'histoire de l'Asie Portugaise (Paris: Fondation Calouste Gulbenkian, 1997), 135-53.

5 Mauss, M. "Essai sur le don. Forme et raison de l'échange dans les sociétés archaïques." l'Année Sociologique. Nouvelle série 1 (1923-1924), 30-186. The peace ideals behind this work cannot be detached from interwar Europe's intellectual environment and its global ramifications. Liebersohn, H. The Return of the Gift: European History of a Global Idea (Cambridge: Cambridge University Press, 2011). On post-Mauss theories on the gift, see Sykes, K. Arguing with Anthropology: An Introduction to Critical Theories of the Gift (New York, Routledge, 2005).

6 Different overviews on Portuguese diplomacy in Asia offer meaningful examples in this point. Biedermann, Z. "Portuguese Diplomacy in Asia in the Sixteenth Century: A Preliminary Overview." Itinerario, 29 (2005), 16-18; Halikowski-Smith, S. "The Friendship of Kings Was in the Ambassadors': Portuguese Diplomatic Embassies in Asia and Africa during the Sixteenth and Seventeenth Centuries." Portuguese Studies, 22 (2006), 118-20; Melo, J. "Seeking Prestige and Survival: Gift-Exchange Practices between the Portuguese Estado da Índia and Asian Rulers." Journal of the Economic and Social History of the Orient 55 (2013), 678-82.

7 Harbsmeier, M. "Gifts and Discoveries: Gift Exchange in Early Modern Narratives of Exploration and Discovery." In Negotiating the Gift: Pre-Modern Figurations of Exchange, eds. G. Algazi, V. Groebner, and B. Jussen (Göttingen: Vandenhoeck \& Ruprecht, 2003), 381-410; Córdoba Ochoa, L. "Gift, Imitation, Violence and Social Change: The Introduction of European Products in the First Decades of the American Conquest." In American Globalization, 1452-1850: 
European representatives through gifts and tributes. ${ }^{8}$ It was precisely because both parts relied on their own understandings of gift-giving as a tool for political competition that gift-exchange frequently triggered conflicts. ${ }^{9}$ Building on this scholarship, recent literature on global gifts has emphasized the important role played by diplomatic gifts and tributes in the understanding of political rivalries and shifting power balances across cultural divides. ${ }^{10}$

These works have mainly focused on courtly encounters and the dyadic interaction that characterized diplomacy at the highest levels. This approach has proven particularly useful to identify the driving factors behind the toptier diplomatic conflicts analyzed. However, recent literature on early modern diplomacy has underlined the plurality of actors that shaped the outcome of diplomatic interactions across cultural divides. ${ }^{11}$ This new approach invites us to go beyond single-cause explanations in the analysis of contentious gifts. Violent escalations, like the one here analyzed, seems particularly well suited for that since it involved a wide range of actors and were the result of multiple factors. As we shall see, gifts and tributes pulled the Iberian-Moluccan conflict in different ways and for different reasons. For the sake of clarity, the article follows a thematic and chronological structure that expresses the increasingly important role played by diplomatic gifts in fostering violence. ${ }^{12}$ It starts by addressing a local skirmish caused by Iberian concerns over the Sultan of Ternate's diplomatic gifts. Afterwards, I address the role played by gifts in preventing different attempts to de-escalate the conflict through diplomacy. Then, the focus shifts towards the way in which shared notions about the instrumentalization of tributes as an expression of power asymmetries resulted in new

The Introduction, Reception and Rejection of European and Asian Commodities in the New World, eds. B. Yun-Casalilla, I. Berti, and O. Svriz (New York: Routledge, forthcoming).

8 Klekar, C. "Prisoners in Silken Bonds': Obligation, Trade, and Diplomacy in English Voyages to Japan and China." Journal for Early Modern Cultural Studies 6 (2006), 84-105; Birkenholz, F. "Merchant-Kings and Lords of the World: Diplomatic Gift-Exchange between the Dutch East India Company (voc) and the Safavid and Mughal Empires in the Seventeenth Century." In Practices of Diplomacy in the Early Modern World c. 1410-180o, eds. T.A. Sowerby and J. Hennings (London: Routledge, 2017), 219-36.

9 Burschel, P. "A Clock for the Sultan: Diplomatic Gift-Giving from an Intercultural Perspective." The Medieval History Journal 16 (2013), 547-63; Hennings, J. “The Failed Gift: Ceremony and Gift-Giving in Anglo-Russian Relations (1662-1664)." In Practices of Diplomacy in the Early Modern World c. 1410-180o, eds. T.A. Sowerby and J. Hennings, 237-53. Biedermann, Z., A. Gerritsen, and G. Riello, eds. Global Gifts: The Material Culture of Diplomacy in Early Modern Eurasia (Cambridge: Cambridge University Press, 2018).

11 Tremml-Werner, B., and D. Goetze. "A Multitude of Actors in Early Modern Diplomacy." Journal of Early Modern History 23 (2019), 407-22.

12 I am not analyzing gifts but descriptions of them. Only a few Iberian presents survived in the regalia collections of Moluccan sultans. Wall, V. "Het museum Kedaton van Ternate. Korte beschrijving met catalogus." Oudheidkundig Verslag, 4 (1922), 144, 146-47 and 152. 
episodes of indigenous-driven violence. The closing section explains how diplomatic gifts affected the decision-making processes that led to the conquest of Ternate and large-scale war in the Moluccas.

\section{Threatening Gifts in a Conflictual Archipelago}

The contentious diplomatic gifts here analyzed were closely associated with the warring context of the late sixteenth century Moluccas, but, at the same time, contributed to shape such a conflictual setting. The Moluccas were notorious for being the setting for endless conflicts for the control of the clove trade during the sixteenth and seventeenth centuries. The arrival of the Portuguese in 1513 and the Spanish in 1521 added a new layer of complexity to the traditional rivalry between the sultanates of Ternate and Tidore, which competed for hegemony in Moluccan politics. The Portuguese secured a privileged position in the clove trade after their settlement in the island of Ternate and expelled their Spanish rivals who, from the 156os onwards, focused on the Philippines. However, the Portuguese presence in Ternate came to an end when the murder of Sultan Hairun triggered a violent rebellion lead by Sultan Babullah, who seized the Portuguese fortress in 1575. In a desperate attempt to counter Babullah's rising power and restore regional equilibrium, the Sultan of Tidore welcomed the defeated Portuguese in his island. The expulsion of the Portuguese from Ternate signaled a new era in the Iberian-Moluccan relations, ending with the conquest of Ternate in 1606 and the subsequent spice wars.

Although the Iberian authorities regarded the expulsion of the Portuguese as a casus belli, the road to a large-scale war against the Ternatan sultans was not a direct or linear one. The Portuguese initiated intense diplomatic contacts in order to maintain a precarious frontier settlement with the support of their local allies. Furthermore, the first move of Sultan Babullah after taking the fortress was to suggest a truce, which the Portuguese rushed to accept. In the following years, the Portuguese continued trading cloves with Ternate from their new settlement in Tidore. ${ }^{13}$ This status quo fell to pieces after the Iberian Union (1580). The Portuguese defended the Moluccas as their exclusive area of influence and maintained their presence in the archipelago with the support of the Sultan of Tidore. The Spanish authorities in Manila, in contrast, tried to gain influence in the Moluccas by arguing that the weak Portuguese presence 
there needed their protection, something which resulted in an increase in armed violence against Ternate. In the 1580s and early 159os, four armed expeditions failed to seize the former Portuguese fortress. To complicate matters further, the English and the Dutch began to reach the Moluccas on a regular basis in the 159os. In their attempt to become the only European traders with access to the Moluccan spices, the Dutch East India Company seized the Portuguese settlements of Ambon and Tidore in 1605. The following year, the Spanish conquered the fortress of Ternate and captured Said Syah. This Pyrrhic victory, however, only ignited a conflict against the Ternatans and their Dutch allies, which ultimately led to the expulsion of the last Spanish garrison in the archipelago in $1663 .{ }^{14}$ As we will see, diplomatic gifts and tributes, played a crucial role in the making of an ideology of antagonism that propelled a material conflict over the spices into a war. ${ }^{15}$

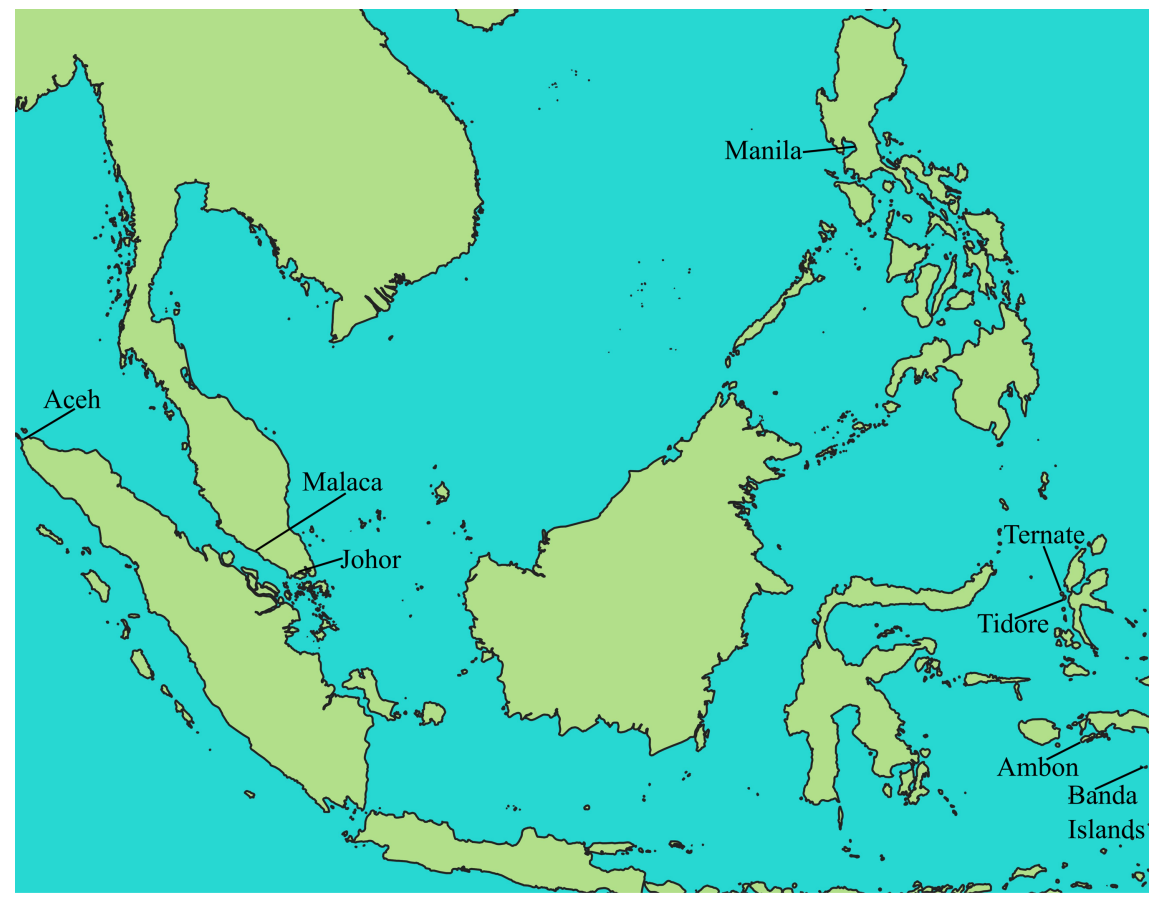
(Macau: Instituto Português do Oriente, 1999), 135-57; Andaya, L. The World of Maluku: Eastern Indonesia in the Early Modern Period, (Honolulu: University of Hawaii Press, 1993), 114-50.

On these processes, see Schröder, I., and B. Schmidt. "Violent Imaginaires and Violent Practices." In Anthropology of Violence and Conflict, eds. I. Schröder and B. Schmidt (London: Routledge, 2001), 1-24. 
Diplomatic gifts lie at the foundations of the violent clashes between Moluccans and Iberians from the mid-1570s. The Iberian authorities used to perceive gifts sent to Ternate as a direct threat. The most obvious example was that of the guns presented to Ternatan sultans. Artillery was a highly appreciated gift in Malay diplomatic culture, and both foreign traders and rulers delivered cannon as a tribute to the Sultan of Ternate in exchange for the right to export cloves. However, the Iberians' saw this practice as the clearest evidence of a diplomatic plot against them. In 1574, Sancho de Vasconcelos (the Portuguese captain in Ambon) received news about a junk near the Banda Islands, sent to Ternate by Ali Jalla, the ruler of Johor. This was a serious matter since by then this ruler was turning Johor (a sultanate in the south of the Malay Peninsula) into a competitor of Malacca in the struggle for the spice trade. The Portuguese captain interpreted that this ship must be carrying an embassy. Even worse, the alleged ambassadors were carrying what Vasconcelos regarded as a dangerous diplomatic present: a large amount of artillery and gunpowder. In a desperate attempt to abort the enemy's embassy, the Portuguese tried to assault the junk. They failed and were forced to withdraw after losing five men, but before leaving they stormed the nearby town of Pulo Haya in retribution for the help it had lent the ambassadors. ${ }^{16}$ This event shows the Portuguese turning what seems to have been nothing but ordinary tribute into a high-ranking embassy transporting extraordinary diplomatic gifts. Even more important, this distortion was used to justify their violent reaction.

The violent reaction caused by the alleged diplomatic gift was closely connected with the Iberian authorities' fears. Their own concerns transformed ordinary tributes into high-ranking diplomatic gifts which embodied their worst nightmares. For the Portuguese, the emergence of an entente between Ternate and Johor was a direct threat to Malacca's spice trade. From the Spanish viewpoint, the main threat was coming from elsewhere. In 1584, officials in the Philippines sent a report to the Council of the Indies listing the multiple reasons to be concerned by Babullah's rising power. One of them had to do with what they deemed to be a very special diplomatic gift:

He has received some long guns from the Turk, which were sent to him as a present. He is very pleased with them because, despite being an Indian, he is a very learned and inquisitive man. ${ }^{17}$

16 Sá, A. Documentaçao para a história das missões do padroado portugês do Oriente. Insulíndia (Lisbon: Agência Geral do Ultramar, 1954), IV, 26o; Pinto, P. "Captains, Sultans and Liaisons Dangereuses: Melaka and Johor in the Late Sixteenth Century." In Iberians in the SingaporeMelaka Area (16th to 18th), ed. P. Borschberg (Wiesbaden: Harrasowitz, 2004), 142. 
Babullah's happiness was grounded in cultural factors. Southeast Asian rulers used to ascribe supernatural properties to their weapons, especially to spectacular foreign-made pieces like these. ${ }^{18}$ These firearms were particularly valuable because of their Turkish origin and the increasing prestige of the Ottoman emperors among local rulers. ${ }^{19}$ However, it is highly improbable that these weapons were a diplomatic gift from Murad III, since there is no evidence for direct diplomatic ties between the Sublime Porte and Ternate. The guns probably came from Aceh's sultan, whose role in the spice trade and diplomatic relationships with the Sublime Porte are well known. ${ }^{20}$ Another possibility is that the guns were a tribute from the Rumî diaspora (Muslims of Anatolian descent) trading in Ternate. ${ }^{21}$ What is really interesting here is that the circulation and redistribution of gifts helped to create connections between parties that were not directly related. From Babullah's viewpoint, this indirect connection with the Ottoman sultans was something to celebrate. However, from his rivals' perspective, these Turkish guns had an alarming meaning: the arrival of Ottoman influence to the Moluccas. The reference to alleged Turkish gifts is revealing about the agency of diplomatic presents in inspiring the Iberian authorities' fears. This evidence was framed by Spanish officials as a call to arms against an enemy which was becoming more and more dangerous because of his global diplomatic contacts. The making of global connections through the circulation and redistribution of diplomatic gifts, combined with Iberian fears, ended up fueling their aggressive policy in the Moluccas. However, the increasing hostility and incidents such Vasconcelos' attack did not automatically initiate a large-scale violent escalation. The enemy gifts alone were not enough to trigger violent countermeasures. In fact, the increasing hostility resulting from enemy gifts and the clashes that they caused did not prevent further attempts to deescalate the conflict by diplomatic means.

Reid, A. "Europe and Southeast Asia: The Military Balance." Centre for Southeast Asian Studies Occasional Paper 16 (1982), 3.

19 Lombard, D. Le carrefour javanais: Essai d'histoire globale. II les réseaux asiatiques (Paris: EHESS, 1990), II, 48-51.

Reid, A. "Sixteenth Century Turkish Influence in Western Indonesia." Journal of Southeast Asian History 10 (1969), 395-414; Casale, G. The Ottoman Age of Exploration (Oxford: Oxford University Press, 2010), 124-34; Römer C., and N. Vatin. "Aceh et la Porte dans les années 156o." Turcica 46 (2015), 63-111; Göksoy, H., and A. Peacock, eds. Ottoman-Southeast Asian Relations: Sources from the Ottoman Archives (Leiden: Brill, 2019), I, 33-74. On the diplomatic activity of the Rumî diaspora, see Couto, D. "Entre confrontations et alliances: Aceh, Malacca et les Ottomans (1520-1568)." Turcica 46 (2015), 13-61. 


\section{Failed Gifts and Unsuccessful Attempts to De-escalate the Conflict}

As anthropologists of violence have pointed out, the steps leading up to war are not irreversible and de-escalation may occur for several reasons. Hence, it is important to understand the role of presents in the different decisions that narrowed down the number of options for conflict resolution to violence. ${ }^{22}$ As we will see, the failure to match diplomatic gift-giving with the inner workings of local diplomacy and politics was also a factor in the violent escalation. The most obvious example were the failed attempts to deescalate the conflict around the Portuguese fortress. Both parts, the Sultan of Ternate and the Portuguese authorities, explored diplomatic means to cool down the conflict and gift-giving had a crucial role to play in this.

The first move in this direction was made by Sultan Babullah. Salvador Muñoz, an eyewitness, reported that when the ruler was informed of the Iberian Union, he decided to send an embassy of eight kora-koras with a present of two bahars (around 1,0oo pounds) of cloves for the Spanish authorities. According to Muñoz, Babullah aimed to start negotiations to deliver the Portuguese fortress and establish a commercial relationship with Manila. Sending such a huge amount of cloves was a good way to begin trade negotiations, given the keen interest that the Spanish authorities in the Philippines had shown to gain access to the spice trade. However, Babullah proved unable to grasp the complex relationship between the authorities of the Estado da Índia and the Philippines. Since 1580 both were subjects of Philip II, but they followed different agendas which were difficult to accommodate. The Spanish never abandoned their projects to conquer the Moluccas and considered the Portuguese as unreliable partners. The Portuguese defended the Moluccas as their exclusive area of influence but relied on the military support of Manila. ${ }^{23}$ As Muñoz reported, when Babullah made public his decision to send the gift, the Portuguese captain of Tidore, Diogo de Azambuja, convinced Babullah not to do it. ${ }^{24}$ By preventing any diplomatic agreement between Ternate and Manila Azambuja was just following what continued to be one of the key pillars of Portuguese politics in the region even during the Iberian Union: preventing the Spanish from entering the Moluccas. Furthermore, local captains like him used to monopolize diplomatic gift-giving in order to defend their

\footnotetext{
22 See note 15.

23 Lobato, M. "As Filipinas e o Estado da Índia no tempo dos Austrias. Tensão, convergência e acomodaçao entre os imperios ibéricos na Ásia do sueste." In Portugal na Monarquia Hispânica: Dinâmicas de integraçao e de conflito, eds. P. Cardim, L. Costa, and M. Cunha (Lisbon: CHAM, 2013), 277-308.

24 AGI, Filipinas, 34, 73, fols. 7-8 and 29.
} 
private interests. ${ }^{25}$ In a nutshell, Babullah chose the right presents, but he felt trapped in Iberian internal divisions.

Babullah was not the only one failing to deescalate the conflict through gift-giving. In 1584, Duarte de Meneses, the Portuguese viceroy of the Estado da Índia, turned to diplomacy to have the Portuguese fortress in Ternate restored. He sent an embassy with three pieces of textiles, a pipe of wine and a hat to be delivered after the fortress had been returned. The embassy, however, was a complete failure. Diogo de Azambuja advised the ambassador Artur de Brito to deliver the gifts to Babullah at the start of negotiations, but Brito decided to follow the viceroy's instructions. In addition, he did not follow Ternate's diplomatic etiquette and delivered the viceroy's letters to Babullah without giving him the presents that they mentioned. Babullah rejected the letter saying that it was not addressed to him, since he was not being given what the letter said he would. Finally, when Babullah heard that the presents were to be delivered after the restitution of the fortress, he laughed and said that he was not delivering his fortress "in exchange for four pieces."26 The authorities in Goa and the Peninsula blamed the ambassador for the failure to recover the fortress. ${ }^{27}$ However the whole embassy was poorly planned from the start. Not only the authorities in Goa gave him specific orders which did not fit with the protocol of Moluccan diplomacy, but the value of the presents did not match what was expected in exchange. The viceroy ambassador's ignorance of Moluccan diplomacy, Babullah's unawareness of the rifts that separated the Iberian empires, and Azambuja's manipulation led to the failure of all attempts to de-escalate the conflict.

The failures adapting diplomatic gifts to the goals of both sides' attempts to de-escalate the conflict may lead us to assume that the it was the huge cultural divide between Molucans and Iberians what contributed to make gift-giving a driving force of the conflict escalation. However, as we will see in the following section, in order to fully understand the complex roles of gifts and tributes in this violent escalation it is necessary to explore how shared ideas on tributes may have contributed to spark violent clashes and increasing tensions between them.

25 Pinto, P. Portugueses e Malaios. Malaca e os Sultanatos de Johor e Achém 1575-16ry (Lisbon: Sociedade histórica da Independência de Portugal, 1997), 145-46.

26 "E dizia zombando, que a sua Fortaleza a não entregava por quatro pessas." Couto, D. Decadas da Asia. Decada décima, parte segunda (Lisbon: Regia Officina Typografica, 1788), 37 and 274-84.

Arquivo Historico Ultramarino (hereafter A HU), Conselho Ultramarino, Codice 281, fol. 125 . 


\section{Contentious Tributes and Violence between Allies}

In addition to the increasing antagonism between Ternate and the Iberians, the relationship between the latter and their Moluccan ally, the Sultan of Tidore, also deteriorated. The Portuguese presence in Tidore was grounded on their agreement with its ruler and, as usual, the payment of tributes was a key part of it. As we have seen, some Portuguese authorities failed to adapt to Moluccan diplomatic etiquette. This was not the case regarding the arrangement of a tributary agreement with the Sultan of Tidore. Such arrangement profited from a shared understanding of the political meaning of tribute. However, the changing nature of the power balance between the Iberians and their Moluccan allies turned shared notions on the political meaning of tributes and power asymmetries into a new source of violent conflicts.

The far-reaching changes in the volume and nature of these tributes tells us a good deal about the shifting nature of power asymmetries and how they were perceived by each side. For the Sultan of Tidore, the tributes from his Portuguese guests were of utmost importance. Foreign goods played a key role in the internal politics of the archipelago. A small proportion of the diplomatic presents were set aside to make up the pusaka (regalia) of the sultans, but the lion's share went out of the rulers' hands. Once foreign goods entered the socio-political arena of the Moluccas, they became a strategic commodity exchanged for support and loyalty. ${ }^{28}$ From the fifteenth century, these islands witnessed a process of political transformation which went hand in hand with the boom of the spice trade. The European demand for cloves only contributed to fuel the ongoing centralization of spice production in the hands of the sultans of Tidore and Ternate. Cloves were presented to them by their subjects in exchange for foreign goods, which their subjects stored and used for ceremonial purposes. This symbolic exchange played a crucial role in forging and reinforcing the political bonds that held the community together. ${ }^{29}$ The increasing flow of foreign goods from the spice trade and their later commodification in the arena of domestic politics fueled competition among local rulers, because the amount of foreign goods they could obtain and redistribute among kolani (lords) and sengaji (governors) determined their capacity to keep and extend

28 I rely here on Appadurai, A. "Commodities and the Politics of Value." In The Social Life of Things: Commodities in Cultural Perspective, ed. A. Appadurai (Cambridge: Cambridge University Press, 1986), 3-63.

29 Villiers, J. "The Cash-Crop Economy and State Formation in the Spice Islands in the Fifteenth and Sixteenth Centuries." In The Southeast Asian Port and Polity, ed. J. Kathirithamby-Wells (Singapore: Singapore University Press, 199o), 83-105; Andaya, L. The World of Maluku, 5657 and 77 . 
their domains. Welcoming the Portuguese in his islands, the Sultan of Tidore not only gained a military ally against his rival, but also more tributes from the clove trade.

The Portuguese authorities showed the ability to adapt to local tributary practices and, even more important, to the changing power relations they mirrored. According to the official records, the Sultan of Tidore was compelled to pay 100 bahaars of cloves each year as pareas, a term for tribute paid in exchange for military protection. This reflects the predominant position held by the Portuguese when they were the only European power in the archipelago. However, the arrival of other foreign powers and their own weakness made them lose leverage in their relationship with the Sultan of Tidore. As a result, in the last quarter of the sixteenth century the Portuguese had to pay for these cloves. ${ }^{30}$ Arrangements like this were far from being unusual in Southeast Asia and the Portuguese proved able to adapt to it. Clear proof of it were the set of norms they developed in order to determine who had to pay for the tributes that the local kings demanded in exchange for trading rights. The Portuguese continued referring to the goods delivered to rulers like the Sultan of Tidore as dádivas, a term that can be translated as present, since it refers to freely delivered goods. However, the Portuguese authorities assimilated these "gifts" to actual tributes, since according to their norms only those who contributed to fund the dádivas could profit from the trading agreements derived from them. ${ }^{31}$ Unfortunately, the Iberian Union altered the tributary agreement between the Sultan of Tidore and his Portuguese allies.

From the very beginning, the authorities in Manila proved unable to understand or accept the tributary agreement with the Sultan of Tidore. After the news about the Union of the Iberian Crowns arrived, the alliance of Gapibaguna, the Sultan of Tidore with the new king of Portugal, Philip II, had to be formalized. In order to do that, a letter was sent to Gonzalo Ronquillo (the governor of the Philippines) offering Gapibaguna's vassalage. The letter ended addressing a crucial issue in Moluccan diplomacy: gifts. Gapibaguna sent two bahars of cloves. This present showcased the potential of the future relationship that Gapibaguna was trying to establish with Manila. By sending cloves, he acknowledged the Spanish wish to enter the spice trade. He also tried to reinforce his position vis-à-vis Ternate by including the Spanish in his previous dealings with the Portuguese and thus increasing the political profits that he yielded from the clove trade. In exchange for this gift, Gapibaguna

30 AHU, Conselho Ultramarino, Codice 217, fol. 131; Lobato, M. Política e comércio, 121-122, 137 and 231.

31 Arquivo Nacional Torre do Tombo, Ms Livraria, 805, fols. 169-170. 
would accept "a light coat of mail... a Spanish crossbow... another crossbow from China, a knife and two good golden scissors". The letter closed with an apology for his requests "please, Your Lordship, do not get angry with these demands since a foreigner eager for good stuff has these discomfitures." ${ }^{32}$ Instead of getting a polite answer from the governor of the Philippines, he had his demands rejected:

I would love to have in this land all the things Your Lordship asks me for, but contrary to what people says, they are not available in these islands, because here we are all soldiers, and we only care about having good weapons and enough ammunition. However, the captain Juan Ronquillo will give you on my behalf some trifles from the things that are available here. ${ }^{33}$

The governor's rejection of the sultan's requests was a clear example of how he conceived gift-exchange as a tool to threat his new Moluccan ally. Furthermore, it shows his own view on the power asymmetries between the Iberian authorities and the Moluccan sultans and mirrors the bitter side of aggressive rule in the Philippines. ${ }^{34}$ By sending "some trifles" to Gapibaguna he was expressing the low status that he conferred this new subject of Philip II. The nature, quality and timing of the presents that the Spanish governors sent him in the following years express the status they granted him and what they expected from him in return. An examination of the financial records allows us to understand the place he held in the diplomatic agenda of Manila's governors. In 1583 "three big pieces of Chinese silks decorated with birds" were bought to be sent to Gapibaguna, together with a great amount of "green velvet from Castile." Similarly, four years later, "four pieces and two pounds of silk, together with six ounces of civet

32 "Huma saya de macha boa... e huma ballesta ao uzo d'espanha... e outra ballesta ao uzo da china e hum canyveto e huãs tisoras douradas bem feytas. Não se enfade v s con este pititorios porque hum estraneiro e famyto de cousas boas tenhe estos descontos."AGI, Filipinas, 34, 43 .

33 "Las cossas que Vuestra Señoría me pide, quisiera yo que en esta tierra las hubiere tan abundantemente como lo signiffican. Pero como aquí todos somos soldados no se tiene cuidado sino de lo que toca a tener buenas armas y muniçiones, mas de lo que aquí ay dara a Vuestra Señoría de mi parte el cappitan don Juan Ronquillo algunas menudençias." AGI, Patronato, 24, R.58.

34 Spanish rule over the Philippines was considered more benign than over the Americas. Phelan, J. The Hispanization of the Philippines: Spanish Aims and Filipino Responses, 15651700 (Madison: University of Wisconsin Press. 1959). However, this conquest also resulted in significant depopulation. Interestingly, tribute exaction and the hate against Muslims, played a key role in it. Newson, L. Conquest and Pestilence in the Early Spanish Philippines (Honolulu: University of Hawaii Press, 2009), 24-36. 
musk" were sent to him on behalf of the governor of the Philippines. At any rate, these presents were better than the robes, glass beads and broken harquebuses received by a chief of the Sambal (an ethnic group from central Luzon) after the pacification of Pampanga. ${ }^{35}$ However, they were nothing compared to the 800 pesos that the governor invested every year in gifts for Japan. ${ }^{36}$ The timing of the gifts is also quite meaningful. The governor of the Philippines and his captains used to send presents for the Sultan of Tidore as part of the preparations for his armed expeditions against Ternate. ${ }^{37}$ The timing, amount and nature of the gifts of the Spanish authorities show that they considered Gapibaguna a lower rank partner in their struggle against Ternate. Hence, the establishment of a tributary relation like the one that existed between Gapibaguna and the Portuguese was completely out of the question from their point of view.

The gift-giving relation between the governor of Manila and the Sultan of Tidore had a direct impact on the tributary relations between the latter and his Portuguese guests. Sending presents sporadically when a service was required was enough from the Spanish viewpoint, but from Gapibaguna's perspective this was clearly not sufficient. As noted, foreign gifts and tributes were a crucial commodity exchanged for loyalty in the arena of Moluccan politics. This led the two main regional powers, the sultans of Ternate and Tidore, to try to get their hands in as many foreign goods as they could. By the 1580s, the sultans of Ternate had established an efficient system to collect tributes from foreign traders. A Spanish witness reported that: "The king of Ternate had expressly ordered his captains in the island of Ambon to not allow the passage [towards Ternate] of any foreign ship that does not bring artillery, harquebuses and ammunitions." ${ }^{38}$ The same account also shows that the sultan redistributed most of these weapons among the rulers of the different islands to cement his authority over them. The Moluccan sultans were quite attentive to the presents or tributes their rivals received and reacted to them. ${ }^{39}$ At a time when his traditional rival was increasing his power with the aid of foreign tributes,

35 AGI, Contaduría, 1200, fols. 979-80, 1247 and 1052. Maybe these presents were chosen to adapt to the recipient's taste. Golombek, L. "The Draped Universe of Islam." In Content and Context of Visual Arts in the Islamic World, ed. P. Soucek (University Park: Pennsylvania State University Press, 1988), 25-38.

36 AgI, Filipinas, 29, 94 and Tremml-Werner, B. Spain, China, and Japan in Manila, 1571-1644: Local Comparisons and Global Connections (Amsterdam: Amsterdam University Press, 2015), 193-208.

37 AGI, Contaduría, 1200, fols. 979-8o and 1247; and Patronato 52, R.15, fol. 10.

38 AGI, Patronato, 46, R.18, fol. 4.

39 Thomaz, L. "As cartas malaias de Abu Hayat, Sultão a El-Rei de Portugal e os primórdios da presença portuguesa em Maluco." Anais de História de Além-Mar 4 (2003), 442. 
Gapibaguna could not accept the sporadic delivery of diplomatic gifts. He needed instead to ensure a regular stream of tributes similar to his rival's. Since it was impossible for him to impose a tributary relationship on the powerful and distant governor of Manila, the sultan decided to turn the screw on his Portuguese guests.

In an attempt not to fall behind his rival, Gapibaguna tried to renegotiate the tributary status of his Portuguese guests. In the past the Portuguese had shown certain flexibility to adapt to a tributary system that mirrored the changing nature of power asymmetries. However, this time negotiations were all but easy. The increasing demands of Gapibaguna led to bitter reactions. The letter addressed to Philip II in 1597 by the captain Julião de Noronha is quite clear in this regard. According to him, the Sultan of Tidore

does many grievances to these people... like cutting off fishing and the food supply plenty of times, just to make clear that we will be here for as long as he wants, and forcing the captains to give him more presents ( $d a^{-}$ divas), which are paid from His Majesty treasure, but he wants so much that it is as though he was not a vassal of His Majesty. ${ }^{40}$

As the letter clearly indicates, Gapibaguna did not hesitate to use violence against his Portuguese guests and allies in order to increase their generosity. Gapibaguna's attitude can be understood as an attempt to force his guests to pay the tributes they were due or to increase the amount. What is clear is that Noronha, despite using the term dádiva, was denouncing that this really was nothing but exacting tributes. This is why he underlined that, by asking for too many dádivas, the Sultan of Tidore was not behaving as a vassal of His Majesty. Furthermore, given that these gifts were being funded from His Majesty treasure, the obvious conclusion was that Philip II was paying páreas to a greedy sultan.

Gapibaguna's attitude proved successful and, in fact, the Portuguese authorities deployed in Tidore did their best to satisfy his demands, but this did not prevent further violent tensions. According to Noronha, the former captain of the Portuguese fortress of Tidore, Diogo de Azambuja, presented a horse to Gapibaguna. Horses were an efficient diplomatic tool commonly used by the

40 "Ele faz muitos agravos a este povo... he tolher muitas vezes no ano que não pesquen nem nos vendão manetinimentos, tudo a fim de dar a entender que estaremos aqui en coanto ele quizer e para os capitães lhe darem muytas dádivas as coaes lhe dão da fazenda de Vosa Magestade, mas quer tantas que lhe não lembra que he vaçalo de Vossa Magestade"AGI, Filipinas, 35, 11. 
authorities of the Portuguese Estado da Índia since they were highly coveted by Asian rulers. We can assume that the horse became one of the most valuable assets for Gapibaguna's regalia. ${ }^{41}$ Unfortunately, even highly appreciated gifts caused violent clashes. The horse was accidentally wounded by a merdica (local Christian) or a Portuguese casado, and the sultan had him hanged in retribution. Such disproportionate punishment shows to what extent Gapibaguna appreciated the horse, but also his violent disdain towards his Portuguese allies. When the Portuguese captain complained about this excessive punishment, Gapibaguna rudely ordered him to cure the horse before it was too late. As Noronha bitterly lamented, the Portuguese captain and his men rushed to do so "because we always adhere to his will owing to the little power we have here." ${ }^{\prime 2}$ As Noronha tried to denounce, what lay behind the horse incident was a power asymmetry between the sultan and his guests. The sultan's rude threat and the Portuguese docile response showed to what extent Gapibaguna was able to impose his will over his Iberian guests. Like the Spanish governor of the Philippines before him, he was using gifts to send a violent threat to his allies.

The picture emerging from these stormy interactions is that of a negotiation in which the different parts relied on the exchange of gifts and tributes to assert their own position. All agreed on something crucial, that gifts and tributes were a suitable tool to establish their own status and that of others. However, they all disagreed on who had the upper hand in their power asymmetries. The frictions between Gapibaguna, the Portuguese and the Spanish did not result from a cultural misunderstanding on the different meaning of diplomatic gifts and tributes, but on their attempt to impose their own views. ${ }^{43}$ Their alliance survived these tensions, but the distrust towards the Sultan of Tidore continued being a matter of concern for the Iberian authorities. Quite meaningfully, in future plans to conquer the Moluccas these tensions and distrusts were seriously considered..$^{44}$ In a nutshell, a shared understanding of the political meaning of tributes contributed to the escalation of violence in the archipelago.

41 Boomgaard, P. "Horse Breeding, Long-Distance Horse Trading and Royal Courts in Indonesian History, 1500-19oo." In Breeds of Empire: The 'invention' of the Horse in Southeast Asia and Southern Africa, 1500-1950, eds. G. Bankoff and S. Swart (Copenhagen: NIAS Press, 2007), 33-34. Sending animals was a well-established Islamic diplomatic tradition. Rogers, M. "The Gorgeous East: Trade and Tribute in Islamic Empires." In Circa 1492: Art in the Age of Exploration, ed. J. Levenson (New Haven: Yale University Press, 1991), 72. "Pelo pouco poder que aqui temos se lhe fez a vontade."AG I, Filipinas, 35, 11.

43 On the complex and changing interpretations of gifts and tributes in cross-cultural communication, see Windler, C. "Tribut und Gabe. Mediterrane Diplomatie als interkulturelle Kommunikation." Saeculum $5^{1}$ (2000), 24-56. 


\section{Global Gifts and the Making of a Global Enemy}

The last stage in the run up towards open war was characterized by the armed expeditions that the Iberian authorities organized to recover the fortress in Ternate and by the Spanish conquests so, in order to understand the violent escalation that followed, special attention needs to be paid to their motivations. After the arrival of the English and the Dutch the military intervention in the Moluccas became a matter of self-protection, not only for Manila. Remarkably, diplomatic gifts played a key role in promoting and spreading this new threat and critically bringing matters to a violent head. As we will see, from the point of view of the Iberian authorities in the region, the gifts the English and the Dutch sent to, and received from, the Sultan of Ternate contributed to turn him into a global enemy.

Diplomatic gifts contributed to the making of this new global enemy in a progressive manner. In November 1579, Francis Drake reached Ternate. During his visit, the Englishmen had the chance to admire Babullah's regalia and gave him some presents as "a farther confirmation of that good liking and friendship already begunne."45 The Iberians reported on Drake's visit paying special attention to the gifts he had exchanged with Babullah. In his annual letter of 1580, Gomes Vaz, a Jesuit from Malacca, gave an account of Drake's recent visit to the Moluccas and made reference to a gift that we have already encountered. According to Vaz, Drake received from Babullah: "a signet from the king of Ternate, as a safe-conduct." According to rumors he had heard, in exchange for this gift Drake promised to come back with a fleet. ${ }^{46}$ The officers in Manila reported this exchange of gifts in a more dramatic way. In the summer of 1582, the captain Juan Pacheco Maldonado wrote to the viceroy of New Spain to update him on the situation in the Moluccas and referred to Drake's expedition in the following terms:

The Englishman went to the port of Ternate... and he was so clever, that he made an alliance with the sultan by giving him some things that he had stolen there [in the Americas]. They remained as true friends and agreed that he would come back soon to expel the Portuguese and the Spanish from his lands. And they agreed that, on the Englishman's return, the king of Ternate would deliver the fortress to them. ${ }^{47}$

46 "Levando hum sinete d'el-rey de Ternate de seguro." Jacobs, Documenta Malucensia, II, 93.

47 "Fuese el inglés al puerto del rey de Ternate... y allí tuvo tal maña que se confederó con el dándola algunas cosas de las que por allá avia hurtado. Quedaron muy amigos y 
The officer continued setting out the dangers posed by the arrival of this enemy, namely the end of Spanish expansion or the collapse of the Estado da Índia, and asked for military reinforcements to conquer Ternate before an imminent English attack. Unsurprisingly, the presence of European competitors was understood as a dangerous threat to Iberians interests in Southeast Asia. What is more interesting for us here is that their presents were being used by Manila's authorities in order to call for more military resources for their struggle against Ternate. However, contrary to what happened in the 16oos, when this ring became matter of debate at a global scale (as we have seen in the introduction) the references to this gift had no significant impact.

As noted in the first section, the authorities in Manila had been referring to the Sultan of Ternate's global gifts in their attempt to portray him as a mighty enemy since the $158 \mathrm{os}$, but their reports had had no significant effect. However, in the turn of the seventeenth century, references to similar global gifts gained momentum and began reverberating in the political communications of the Iberian empires. In order to understand why, it is crucial to bear in mind that in the last decades of the sixteenth century and the opening years of the seventeenth century the English, and especially the Dutch, had arrived in force in Southeast Asia, inflicting serious damage to the Portuguese interests in the region. As a result, the Portuguese authorities (from Tidore, Malacca and Goa) prioritized the fight against the Dutch threat. ${ }^{48}$ Something similar happened in the Philippines, where the Dutch became the most dangerous threat from the point of view of the Spanish authorities. ${ }^{49}$ Nevertheless, what really made a difference was that now the news about Ternate's global gifts began reflecting fears that were already lodged in the decision-making of the Iberian empires. ${ }^{50}$ The Spanish and the Portuguese authorities (not only in Malacca or Manila) perceived the forging of an alliance between the Dutch and the Sultan of Ternate as the worst of their nightmares. As a result, and in sharp contrast with previous expeditions organized by the governors

concertados de que el volvería con mucha brevedad allí y le henchiría la mar de navíos y echaría los portugueses de la tierra y aún los españoles. Y quedaron que si volviese le estregaria el rey de Ternate aquella fortaleza."AG I, Filipinas, 34, 47.

48 Loureiro, R. "Early Portuguese Perceptions of the 'Dutch' Threat in Asia." In Rivalry and Conflict. European Traders and Asian Trading Networks in the 16th and 17th Centuries, eds. E. van Veen and L. Blussé (Leiden: CNWS, 2005), 166-87.

49 Sanchez, J-N. "A Prismatic Glance at One Century of Threats on the Philippine Colony." In The Representation of External Threats: From the Middle Ages to the Modern World, eds. E. Crailsheim and M. Elizalde (Leiden: Brill, 2019), 357-59.

50 On the circulation of these nightmares, and their connection with violent strategies, see Pérez Tostado, I. "La globalisation de la peur: massacre et altérité, entre empires espagnol et britannique dans la premiere moitié du XVIIe siècle." Itinera 38 (2015), 131-55. 
of Manila like that of 1593, the expeditions before the conquest were large scale operations that brought together military resources at a global scale. ${ }^{51}$ As the study of other Iberian conquests in Asia has shown, such large-scale military operations were the result of interactions and negotiations between different decisional cores of the empire. In other words, in the fragmented and decentralized Iberian empires a conquest like that of Ternate required a great deal of negotiation between Madrid, Lisbon, Malacca, Manila, Goa and Mexico.52 For instance, in 16o1 the Spanish viceroy of New Spain, who provided many of the troops sent against Ternate, justified his support to this enterprise by referring to its alliance with the European enemies of the empire and the serious threat it represented. ${ }^{53}$ It is in this framework that Ternate's global gifts played a key role in the final phase of violent escalation.

The clearest illustration of how the news of diplomatic gifts sent from Ternate fuelled the violent strategy that led to the conquest is a royal letter dated to early 1603. In this letter, King Philip III ordered Aires de Saldanha, viceroy of the Estado da Índia, to take urgent measures to stop Dutch penetration in the Moluccas, because Sultan Said Syah had sent "a basket of earth to the Queen of England or Count Mauritius." This intriguing gift conveyed a message: the ruler accepting the basket would be compelled to send a fleet to expel the Portuguese from the Moluccas. In exchange, according to the letter, Said Syah was promising to send the ships back full of cloves. The king's account of such a dangerous diplomatic present was followed by an order to organize a fleet and send it to the Moluccas to prevent the Dutch from taking control of the archipelago. ${ }^{54}$ This royal command shows that the Iberian authorities perceived the diplomatic agreements between the Sultan of Ternate and their European rivals as a direct threat to their interests, justifying military intervention. In a nutshell, it shows that the reference to specific diplomatic gifts led the Iberian authorities to adopt an increasingly violent strategy in the region.

The letter shows that the Iberian authorities, not only on the ground but also in the metropolis, tried to get a firm grasp on Moluccan gift-giving practices and incorporated it to their decision-making processes. As noted, previous calls to arms related to news about gifts were grounded on the projection

\footnotetext{
$5^{1}$ Crossley, J. The Dasmariñases, Early Governors of the Spanish Philippines (London: Routledge, 2016), 166-77. Jacobs, Documenta Malucensia, II, 561-71; AG I, Filipinas, 1, 36, fol. 3.

52 Biedermann, Z. (Dis)Connected Empires: Imperial Portugal, Sri Lankan Diplomacy, and the Making of a Habsburg Conquest in Asia (Oxford: Oxford University Press, 2018), 144-91.

53 AGI, Filipinas, 1,48 , fol. 7 .

54 "Hum zesto de terra ofereçido a rainha da Ingallaterra ou á o comde Mauriçio" AHU, Conselho Ultramarino, Codice 282, fol. 141.
} 
of European meanings to Molucca gifts, Drake's ring being the most obvious example. Other times, their assessment of the items exchanged by their enemies were completely wrong. This was the case, for instance, with all those tributes that became important diplomatic gifts in the eyes of the Iberian authorities. Any gift exchanged between enemies was a threat, but, unlike with Drake's ring, the specific meaning of such a strange gift as the basket of earth was difficult to understand from a European perspective. However, the interpretation included in the royal letter is astonishingly similar to that made of similar gifts. In an account of the surrender of the inhabitants of Ambon to Portuguese forces written in 1602, a similar present of earth and clove branches was understood as "a sign that they delivered the land and its main produce to them." ${ }^{55}$ It is easy to take for granted that misunderstandings or wrong assumptions about alien diplomatic cultures drove the conflict to a violent end. In this case, a supposedly more accurate understanding of the enemy's diplomatic practices only helped to escalate the conflict. Paradoxically, the same present that brought the conflict in Ambon to and end contributed to promote the Iberian offensive. In fact, the royal letter and the news about this diplomatic gift cannot be detached from the Iberians' decision to conquer Ternate. By the time the letter departed from Lisbon, the Council of the Indies, had already discussed and decided the organization of the fleet that would ultimately take Ternate. ${ }^{56}$ The factor that encouraged the Council to adopt a violent strategy was not the degree of (in)commensurability of the enemy's diplomatic culture, but the potential danger attached to his diplomatic contacts.

\section{Conclusion}

The road that led from conflict to conquest was neither straightforward nor direct. Several factors played a hand in the violent escalation that led to open war. The problematic relations between Iberians and Moluccans (either foes or allies), internal political divisions in the Iberian empires, Moluccan traditional rivalries, and European competition all contributed to spark violence. Diplomatic gifts and tributes played a key role in increasing the level of violence in relation to all of these factors. The diplomatic gifts sent or received by the sultans of Ternate always

55 "Em sinal que lhe entregavão a terra e o principal fruito della." Jacobs, H. Documenta Malucensia, II, 563 .

$5^{6}$ AGI, Filipinas, 1, 48, fols. 13-15. The meaning of such exchanges in Ambonese peacemaking ceremonies was different and had more to do with their animistic believes. Knaap, G. "Headhunting, Carnage and Armed Peace in Amboina, 1500-1700." Journal of the Economic and Social History of the Orient 46 (2) (2003), 173. 
ringed the alarm for the Iberian authorities. However, there is a striking difference in terms of consequences. Whereas in the late 1570 os and early 1580 os they merely led to simple skirmishes or unnoticed reports, in the 1600 s they were taken as a global bugle call to arms. This striking difference shows how the perception of enemy gifts changed over time, but even more important, it shows the contingent agency of these gifts in bringing the fears of the Iberian authorities to life. The gifts alone were not enough cause to fear the alliance between Ternate and the Dutch, but they certainly contributed to create a consensus among the different decisional bodies about the need to violently tackle such threat. In so doing they helped to mobilize the resources needed to transform a regional conflict into a global one. The role of global gifts in turning the Sultan of Ternate into a global enemy only crystallized at the very end of the conflict. Before that, the situation had dramatically deteriorated in different directions and diplomatic gift-giving and tributes had played a key role in this. Sultan Babullah, as well as the Portuguese viceroy, tried to de-escalate the conflict around the fortress by diplomatic means. Both relied on a shared gift culture as an asset which could facilitate these negotiations, but both failed to meet their targets. The inability to decode diplomatic and political cultures derailed the attempts to deescalate the conflict. However, not all the Moluccan-Iberian interactions that led to violent escalation can be understood in terms of this incommensurability. The troublesome relationship between the Iberian authorities and the Sultan of Tidore after the Iberian Union were the result of a shared understanding of how the language of gifts and tributes revealed asymmetries of power.

Gifts and tributes played different roles in the violent escalation that engulfed the Moluccas in the late sixteenth century. The analysis of the multiple ways in which diplomatic gifts and tributes contributed to this violent escalation shows the need to go beyond previous interpretations focused either on the incommensurability of different diplomatic cultures or in shared understandings across cultural divides. The violent escalation here analyzed was the result of a wide array of cross-cultural interactions driven by common understandings and dangerous misunderstandings. Both phenomena contributed to turn conversations through gifts and tributes into a fuel for violence. This was the result of the wide array of actors that compounded the complex multilateral conflicts staged on the Spice Islands. The very presence of a multitude of actors means not only the association of different aims and interests to the gifts, but also different ways of understanding (or misunderstanding) the gifts themselves. As our examples have illustrated, in multipolar diplomatic settings like this, instead of trying to reduce all the conflicts on gifts and tributes to a single-cause explanation, it is far more productive to analyze how gift-related frictions ended up triggering an escalation of violence in different ways and for different reasons. 


\section{Acknowledgements}

This article has been funded by a Marie Sklodowska-Curie Action Individual Fellowship from the European Commission, grant agreement H2O2O MSCA IF-2016 GA 748592 (On the Frontiers of Peace: Cross-Cultural Peacebuilding on the Frontiers of the Iberian Empires 1500-80). I am grateful for the feedback on previous versions from Brice Cossart, Jorge Díaz Ceballos, Jorge Flores, Alejandro García Montón, Pablo Hernández Sau, Bruno Martinho and Bartolomé Yun Casalilla. Likewise, this article has greatly benefited from this special issue editors' comments, and the suggestions from the two anonymous reviewers. 